\title{
Viable but Non-culturable Bacteria: Clinical Practice and Future Perspective
}

\author{
Amin Talebi Bezmin Abadi \\ Department of Bacteriology, Faculty of Medical Sciences, Tarbiat Modares University, Tehran, Iran. Phone: +98-2182884883, E-mail: \\ Amin.talebi@modares.ac.ir
}

Received: 20 Feb 2017 Revised: 19 Mar $2017 \quad$ Accepted: 30 Mar 2017

Please cite this article as: Talebi Bezmin Abadi A. Viable but Non-culturable Bacteria: Clinical Practice and Future Perspective. Res Mol Med. 2017; 5 (2): 1-2

Due to intolerable environmental conditions, bacteria learnt to adopt a useful strategy to survive longer which these organisms generally is termed "viable but non-culturable". In the case of exposure to certain stresses (e.g., antibiotics, low metabolites, heavy metal and high $\mathrm{pH}$ environment, etc.), bacteria enter into the VBNC stage. In similar, having the starvation mode of physiology can be called VBNC model. In fact, viable but non-culturable cells (VBNC) are live bacteria, however, they are unable to be cultivated on conventional culture media (1). Because of complexities in culture, observation of normal colonies on solid and broth media is almost impossible for VBNCs. As complexities were observed for successful culture, our clinical practice is in intense lack of a useful present approach to an accurate diagnosis. Basically, the ability to have the VBNC state can help the bacterium to keep the survival chance, but it endangers human health in the case of pathogenic bacteria (2). The first report indicating the clinical relevance of VBNC backs to more than 40 years ago, but still many unanswered questions are left intact (3). The current challenge is that VBNCs are reversible, therefore in many clinical settings, we should have considered them for causing specific infectious diseases. An important issue is that there is no clue that how many cases are indeed reinfections and new infections, whilst we are unable to detect VBNC for many of pathogenic microorganisms. Indeed, there is a long list of bacteria able to enter this dormancy phase. For example, Shigella spp., Helicobacter pylori, Morganella spp., Escherichia coli (including EHEC), Staphylococcus aureus, Listeria monocytogenes, Enterococcus spp., Vibrio spp. (cholera and vulnificus), Yersinia enterocolytica, and Campylobacter jejuni (4-7). As stated, many of infectious agents are initiating diseases which are transmissible and it raises concerns for better hygiene and health policies. Moreover, our diagnostic laboratories should be also sensed to prevent the occurrence of local and national epidemic.

\section{Are VBNC considered as virulent cells?}

The answer to the above question is not clearly elucidated. The main reply to this query is highly dependent on pathogens. For example, $\mathrm{H}$. pylori is a genetically variable organism which uses many strategies to increase the chance of survival and successful colonization in the human gastric territory $(8,9)$. The harsh gastric condition is the major cause of starvation stage for the cells; resulting in VBNCs forms (10). Following this transformation, the problems are listing for gastroenterologists and microbiologists to design a diagnostic test. The problem with VBNC forms of $\mathrm{H}$. pylori is bound to be transmitted among individuals with close contacts. However, our understanding of the rate of transmission with VBNC forms for $\mathrm{H}$. pylori is not well enough. No need to repeat that more than $20 \%$ of $\mathrm{H}$. pylori infection is bound to reinfection stage $(11,12)$. To everyone's surprise, VBNC forms can serve as the main target for research in answering the query. Therefore, this story can be a paradigm for other pathogenic bacteria we already mentioned! Increasing knowledge of involved mechanisms to survive VBNC cells in human and environment are welcomed.

\section{Current debate}

In clinical practices, we should examine possible molecular approaches for rapid detection of those crucial infectious agents. Recently, the potential of microorganisms to enter into the VBNC phase raised the cautious attention of microbiologists and also clinicians to rethink about current strategies in hospitals and environmental hygiene. The raised central scientific issue is about necessities of any change in guidelines on the management of those problematic infections (13). To my knowledge, it is the time to rethink about at least most of those bacteria to revise a new protocol to have a better therapeutic prescription. Many species of bacteria enter to the VBNC state when they are exposed to stressful conditions such as starvation and low temperatures. The ability to enter the VBNC state may be advantageous for bacteria, but poses a risk to human health (14). Increased knowledge of mechanisms helping the bacteria to enter into the VBNC state is needed to sufficiently improve current preventive strategies against specific bacterial pathogens. In this editorial, the importance of VBNC in clinical practice and future researchinterests has been pinpointed. Accurate detection of VBNC, especially for major mentioned pathogens, is the future research gap.

\section{Acknowledgments}

The contents of this editorial are solely the responsibility of the author and do not necessarily represent the official views of any institute and university.

\section{References}

1. Kell DB, Kaprelyants AS, Weichart DH, Harwood CR, Barer MR. Viability and activity in readily culturable bacteria: a review and discussion of the practical issues. Antonie van Leeuwenhoek. 1998; 73(2):169-87. PMID: 9717575

2. Hayes CS, Low DA. Signals of growth regulation in bacteria. Curr Opin Microbiol. 2009; 12(6):667-73. PMID: 19854099

3. Figdor D, Davies J, Sundqvist G. Starvation survival, growth and recovery of Enterococcus faecalis in human serum. Oral Microbiol Immunol. 2003; 18(4):234-9. PMID: 12823799

4. Tholozan J, Cappelier J, Tissier J, Delattre G, Federighi M. Physiological Characterization of Viable-but-Nonculturable Campylobacter jejuniCells. Appl Environ Microbiol. 1999; 65(3):1110-6. PMID: 10049870

5. Rahman I, Shahamat M, Chowdhury M, Colwell R. Potential virulence of viable but nonculturable Shigella dysenteriae type 1 . Appl Environ Microbiol. 1996; 62(1):115-20. PMID: 8572688 
6. Ramamurthy T, Ghosh A, Pazhani GP, Shinoda S. Current perspectives on viable but non-culturable (VBNC) pathogenic bacteria. Front Public Health. 2014; 2:103. PMID: 25133139

7. Tan SY-E, Chew SC, Tan SY-Y, Givskov M, Yang L. Emerging frontiers in detection and control of bacterial biofilms. Curr Opin Biotechnol. 2014; 26:1-6. PMID: 24679251

8. Abadi ATB. Strategies used by helicobacter pylori to establish persistent infection. World J Gastroenterol. 2017; 23(16):2870 PMID: 28522905

9. Blaser MJ. Ecology of Helicobacter pylori in the human stomach. J Clin Invest. 1997; 100(4):759. PMID: 9259572

10. Bode G, Mauch F, Malfertheiner P. The coccoid forms of Helicobacter pylori. Criteria for their viability. Epidemiology and Infection. 2009; 111(3):483-90. PMID: 8270008
11. Abadi AT, Kusters JG. Management of Helicobacter pylori infections. BMC Gastroenterol. 2016; 16(1):94. PMID: 27520775

12. Talebi Bezmin Abadi A. Time to Stop Helicobacter pylori, no Matter with Antibiotic, Probiotic or Vaccine. Res Mol Med. 2016; 4(3):1-2.

13. Leclerc H, Schwartzbrod L, Dei-Cas E. Microbial agents associated with waterborne diseases. Crit Rev Microbiol. 2002; 28(4):371-409. PMID: 12546197

14. Fakruddin M, Mannan KSB, Andrews S. Viable but nonculturable bacteria: food safety and public health perspective. ISRN microbiology. 2013; 2013. 